\title{
Oxidation and emission of methane in a monomictic lake (Rotsee, Switzerland)
}

\section{Journal Article}

\section{Author(s):}

Schubert, C.J.; Lucas, F.S.; Durisch-Kaiser, E.; Stierli, R.; Diem, T.; Scheidegger, O.; Vazquez, F.; Müller, B.

Publication date:

2010

Permanent link:

https://doi.org/10.3929/ethz-b-000025595

Rights / license:

In Copyright - Non-Commercial Use Permitted

Originally published in:

Aquatic Sciences 72(4), https://doi.org/10.1007/s00027-010-0148-5 


\title{
Oxidation and emission of methane in a monomictic lake (Rotsee, Switzerland)
}

\author{
C. J. Schubert • F. S. Lucas • E. Durisch-Kaiser • \\ R. Stierli $\cdot$ T. Diem $\cdot$ O. Scheidegger $\cdot$ F. Vazquez $\cdot$ \\ B. Müller
}

Received: 25 September 2009/Accepted: 18 May 2010/Published online: 10 June 2010

(C) Springer Basel AG 2010

\begin{abstract}
The build-up of methane in the hypolimnion of the eutrophic Lake Rotsee (Lucerne, Switzerland) was monitored over a full year. Sources and sinks of methane in the water column were characterized by measuring concentrations and carbon isotopic composition. In fall, high methane concentrations (up to $1 \mathrm{mM}$ ) were measured in the anoxic water layer. In the oxic layer, methane concentrations were much lower and the isotopic composition shifted towards heavy carbon isotopes. Methane oxidation rates peaked at the interface between oxic and anoxic water layers at around $8-10 \mathrm{~m}$ depth. The electron balance between the oxidants oxygen, sulphate, and nitrate, and the reductants methane, sulphide and ammonium, matched very well in the chemocline during the stratified season. The profile of carbon isotopic composition of methane showed strong indications for methane oxidation at the
\end{abstract}

Present Address:

F. S. Lucas

Faculté des Sciences et Technologie, Cereve UMR MA 102,

Université Paris 12, 61 ave du General de Gaulle,

94010 Creteil Cedex, France

Present Address:

E. Durisch-Kaiser

Institute of Biogeochemistry and Pollutant Dynamics,

Swiss Federal Institute of Technology (ETH),

Universitätsstrasse 16, 8092 Zurich, Switzerland

C. J. Schubert $(\bowtie) \cdot$ F. S. Lucas · E. Durisch-Kaiser •

R. Stierli · T. Diem · O. Scheidegger · F. Vazquez · B. Müller Department of Surface Waters-Research and Management,

Eawag, Swiss Federal Institute of Aquatic Science and

Technology, 6047 Kastanienbaum, Switzerland

e-mail: carsten.schubert@eawag.ch chemocline (including the oxycline). Aerobic methane oxidizing bacteria were detected at the interface using fluorescence in situ hybridization. Sequencing the responsible organisms from DGGE bands revealed that aerobic methanotrophs type I closely related to Methylomonas were present. Sulphate consumption occurred at the sediment surface and, only towards the end of the stagnation period, matched with a zone of methane consumption. In any case, the flux of sulphate below the chemocline was not sufficient to oxidize all the methane and other oxidants like nitrate, iron or manganese are necessary for the observed methane oxidation. Although most of the methane was oxidized either aerobically or anaerobically, Lake Rotsee was still a source of methane to the atmosphere with emission rates between $0.2 \mathrm{mg} \mathrm{CH}_{4} \mathrm{~m}^{-2} \mathrm{day}^{-1}$ in February and $7 \mathrm{mg} \mathrm{CH}_{4} \mathrm{~m}^{-2}$ day $^{-1}$ in November.

Keywords Methane oxidation - Methane emission · Methane oxidizing bacteria $\cdot$ Lakes .

Redox and flux calculation

\section{Introduction}

Methane, the second most important greenhouse-gas after carbon dioxide and about 20 times more potent than the latter (IPCC 2001), has not only been held responsible for dramatic climate changes in the past (Kennett et al. 2000; Dickens 2003) but also has a significant share on global warming today (Cicerone and Oremland 1988; Rasmussen and Khalil 1984). Presently, more than $71 \%$, or $358 \mathrm{Tg}$ year $^{-1}$, of the emitted methane is of anthropogenic origin, including emissions by energy production, cattle raising, rice fields, land fills, wastewater, and clearing (Wuebbles and Hayhoe 2002) and 18\% of these emissions 
were attributed mainly to tropical and temperate reservoirs (St. Louis et al. 2000). Individual sources of natural methane emissions are not well defined, however, recent publications hint at lakes as an overlooked source (8-48 Tg $\mathrm{CH}_{4}$ year $^{-1}$, Bastviken et al. 2004), representing a significant fraction of all natural emissions (i.e. $145 \mathrm{Tg}$ year $^{-1}$, lakes not included, Wuebbles and Hayhoe 2002). In contrast, much lower numbers $\left(1.2 \mathrm{Tg}\right.$ year $\left.^{-1}\right)$ were given recently for European lakes (Saarnio et al. 2009).

Whereas the process of anaerobic oxidation of methane (AOM) has been traced in the Black Sea water column (Ward et al. 1987; Reeburgh et al. 1991; Schubert et al. 2006) and non-freshwater lakes like Lake Mendota (Panganiban et al. 1979) and Big Soda Lake (Iversen et al. 1987), very little is known from freshwater sediments or water columns, and only one recent publication from a lake water column is available (Eller et al. 2005). In holomictic lakes, excess production of phytoplankton in spring and summer leads to anoxic conditions in bottom waters and organic matter degradation is mediated by anaerobic processes leading to the formation of methane via methanogenesis if no other electron acceptors are available (Conrad 1989). In lakes, this degradation pathway is dominant, whereas in marine systems sulphate reduction by sulphate reducing bacteria is the main process (Jørgensen 1982). Hence, in stratified lakes methane can accumulate to high concentrations $(\sim 20 \mathrm{mmol})$ in the hypolimnion (Schmid et al. 2005).

Methane produced in oceanic sediments is oxidized anaerobically, especially in methane-rich sediments associated with methane hydrates and methane seeps (see reviews by Reeburgh et al. 1991; Hinrichs and Boetius 2002). Zehnder and Brock $(1979,1980)$ first proposed that AOM might be carried out by a consortium of different groups of bacteria. There is now compelling biomarker, isotopic and microbiological evidence (e.g. Hinrichs et al. 1999; Boetius et al. 2000; Pancost et al. 2000; Nauhaus et al. 2002; Orphan et al. 2002) for a consortium consisting of methane-oxidizing Archaea and sulphate-reducing Bacteria. However, some methanotrophic Archaea may oxidize $\mathrm{CH}_{4}$ without tight coupling to a partner (Orphan et al. 2002; Eller et al. 2005). These oxidizing processes are quite efficient, therefore estimates of the amount of gas hydrate-related methane actually emitted to the atmosphere are rather small and reach only $5 \mathrm{Tg} \mathrm{CH}_{4}$ year $^{-1}$ (Wuebbles and Hayhoe 2002).

The transfer of methane from the anoxic hypolimnion to the oxic epilimnion of Lake Rotsee, a $16 \mathrm{~m}$ deep eutrophic lake near Lucerne, Switzerland, and the oxidizing processes involved are discussed in the present manuscript. Our studies over the last 5 years showed that almost all of the investigated lakes and reservoirs in Switzerland are a source for methane (Diem et al. 2008). Similarly for Lake Rotsee, we show that, although most of the methane is oxidized during its way through the water column, the lake surface is still oversaturated in methane compared to the atmosphere and serves as a source of methane. Using methane concentrations and the isotopic composition of methane, we describe its build-up and aerobic oxidation by the bacterial community at the chemocline over a full year.

\section{Materials and methods}

Study site

Lake Rotsee is a small eutrophic prealpine lake near the city of Lucerne in Switzerland. It is $2.4 \mathrm{~km}$ long and $0.4 \mathrm{~km}$ wide and situated at an altitude of $436 \mathrm{~m}$. Its mean depth is $9 \mathrm{~m}$, whereas maximum depth is $16 \mathrm{~m}$. The lake is oligomictic and circulates its deep water annually. However, its wind-shielded setting allows a stable stratification beginning as early as May and ending in late fall (November) depending on prevailing temperature and wind. Lake surface temperature is controlled by atmospheric temperature, while the hypolimnion is rather constant at $7^{\circ} \mathrm{C}$. During stratification, the lake exhibits a strong chemocline $(8-11 \mathrm{~m})$ with an anoxic hypolimnion containing up to $120 \mu \mathrm{mol} \mathrm{L}{ }^{-1}$ sulphide and an epilimnion with up to $170 \mu \mathrm{mol} \mathrm{L} \mathrm{L}^{-1}$ sulphate and occasional large oversaturation of oxygen (up to $580 \mu \mathrm{mol} \mathrm{L}^{-1}$ ). Methane concentrations in a recovered sediment core below the water sampling station were between $0.7 \mathrm{mmol} \mathrm{L}^{-1}$ (surface) and $4.1 \mathrm{mmol} \mathrm{L}^{-1}$ (with one high value of $5.9 \mathrm{mmol} \mathrm{L}^{-1}$ at $15 \mathrm{~cm}$ depth). Sulphate concentrations in the sediment porewater were $<1 \mu \mathrm{mol} \mathrm{L}{ }^{-1}$. More than $90 \%$ of the methane entering the water column from the sediment was generated by acetoclastic Methanosaeta spp., and about $7 \%$ by hydrogenotrophic methanogens in the topmost $2 \mathrm{~cm}$ (Zepp Falz et al. 1999). Ebullition was observed at the shallow littoral zones of the lake.

Sampling, chemical analyses, and flux calculations

A full year's limnological cycle of Lake Rotsee was followed from February 2007 to January 2008 by monthly sampling campaigns. A CTD probe (Seabird SBE19) was used to determine temperature, conductivity, density, light transmission, $\mathrm{pH}$ and oxygen. Water samples were collected with a Niskin bottle with $0.5 \mathrm{~m}$ resolution across the chemocline and every meter above and below this zone. Oxygen concentrations were additionally measured using Winkler titration to ascertain the calibration of the oxygen probe. Water samples for sulphide analysis were filtered immediately through $0.45 \mu \mathrm{m}$ membrane disc filters 
(Whatman, FP30/0.45CA) and $1 \mathrm{ml}$ of $\mathrm{Zn}$ acetate solution ( $4 \%$ in $2 \%$ acetic acid) were added to $1 \mathrm{ml}$ of sample. Photometric analysis (Hitachi U2000) was performed the following day using standard methods (DEW 2004; sulphide: $665 \mathrm{~nm}, \quad 1 \mathrm{~cm}$ cuvette, detection limit $2 \mu \mathrm{mol} \mathrm{L}{ }^{-1}$; nitrate: $420 \mathrm{~nm}, 10 \mathrm{~cm}$ cuvette, detection limit $700 \mathrm{nmol} \mathrm{l}^{-1}$; ammonium: $690 \mathrm{~nm}, 10 \mathrm{~cm}$ cuvette, detection limit $70 \mathrm{nmol} \mathrm{L}{ }^{-1}$; nitrite: $543 \mathrm{~nm}, 10 \mathrm{~cm}$ cuvette, detection limit $35 \mathrm{nmol} \mathrm{L}^{-1}$ ). Samples for sulphate analysis were filtered in the lab with cellulose acetate filters of $0.45 \mu \mathrm{m}$ pore size (Whatman OE67) and analyzed with an ion chromatograph (Metrohm 733, column: Metrosep A Supp 5, $150 \mathrm{~mm} / 4.0 \mathrm{~mm}$ ID, eluent $3.2 \mathrm{mmol} \mathrm{L}{ }^{-1} \mathrm{Na}_{2} \mathrm{CO}_{3}$, $1 \mathrm{mmol} \mathrm{L}^{-1} \mathrm{NaHCO}_{3}$, detection limit $5 \mu \mathrm{mol} \mathrm{L}{ }^{-1}$ ). As the chemical profiles of methane, sulphide, oxygen, and sulphate were always very similar in fall, we include in this study microbiological investigations and accompanying data from an earlier field campaign in October 2005.

Vertical fluxes of chemical compounds across the hypolimnion-epilimnion interface were estimated from concentration gradients, the magnitude of the interface, and the turbulent diffusion coefficient applying Fick's first law of diffusion. Coefficients for turbulent diffusive transport $(k)$ were calculated from temperature profiles from May to October. Transport in the remaining months was dominated by convective mixing and no $\mathrm{k}$ values were calculated.

\section{Methane concentrations and isotopic composition}

Water samples were carefully filled into $120 \mathrm{ml}$ septum bottles avoiding bubbles and turbulences. The samples were poisoned with mercury(I)chloride, closed with a butyl stopper and sealed with an aluminum crimp. In the laboratory, a $20 \%$ headspace volume (helium) was introduced and samples were equilibrated overnight at $30^{\circ} \mathrm{C}$. They were analyzed with a gas chromatograph (Agilent) equipped with a Carboxen 1010 column (30 m, Supelco), a flame ionization detector (FID) and an autosampler. The oven temperature was kept constant at $100^{\circ} \mathrm{C}$. Concentrations were determined using the integrated areas and two different methane standards (Scott, Supelco) with lower and higher end concentrations compared to the measured samples. Methane isotopic composition was determined after cleaning the methane and oxidizing it to $\mathrm{CO}_{2}$ by means of a "Trace gas" (GV Instruments) connected to a mass spectrometer (GV Instruments). Notations are in the $\delta$ notation:

$$
\begin{aligned}
\delta^{13} \mathrm{C}= & \left(\left({ }^{13} \mathrm{C} /{ }^{12} \mathrm{C}_{\text {sample }}\right) /\left({ }^{13} \mathrm{C} /{ }^{12} \mathrm{C}_{\text {standard }}\right)-1\right) \\
& \times 1,000 \% \text { vs. VPDB }
\end{aligned}
$$

\section{Methane oxidation rates}

Water for measuring microbial methane oxidation was collected in triplicate in $20 \mathrm{ml}$ crimp-seal bottles and capped gas-tight. From each triplicate, one sample was poisoned with $50 \mu \mathrm{l}$ concentrated formaldehyde, which functioned as a blank. Aliquots of $50 \mu$ tritiated methane ( ${ }^{3} \mathrm{H}-\mathrm{CH}_{3}, 2.7 \mu \mathrm{Ci}$, ARC S.A.) were added to the bottles and incubated in the dark for $24 \mathrm{~h}$ at ambient temperatures imitating natural conditions. After incubation, the samples were stripped for $30 \mathrm{~min}$ with nitrogen gas to eliminate all unreacted tritiated methane. An aliquot of the stripped sample was mixed with scintillation cocktail (Ultima Gold, Packard) and activity measured in a scintillation counter (Tri-Carb 1600CA, Packard). Turnover rates $[k$ values $\left(\right.$ day $\left.\left.^{-1}\right)\right]$ were calculated from the ratio of tracer reacted in the water to total tracer added. Additionally, we estimated methane oxidation rates from the decrease of methane in $1 \mathrm{~L}$ bottles filled with lake water and incubated imitating in situ conditions over a time period of 3 days.

\section{Methane emissions}

Methane fluxes were calculated using the boundary layer model as described by Liss and Slater (1974):

$F=k \cdot c \cdot\left(C_{\mathrm{w}}-C_{\mathrm{eq}}\right)$

The model estimates the air-water flux $F$ $\left(\mathrm{mg} \mathrm{m}^{-2}\right.$ day $\left.^{-1}\right)$ using the water saturation concentration $C_{\text {eq }}(\mathrm{M})$, the measured water concentration $C_{\mathrm{w}}(\mathrm{M})$ of the greenhouse-gas, the transfer velocity $k\left(\mathrm{~cm} \mathrm{~h}^{-1}\right)$ and a unit conversion factor $c$. For calculation of the transfer velocity $k_{600}$, we used the bi-linear relationship given by Crusius and Wanninkhof (2003) and the relationship given by Cole and Caraco (1998):

$k=k_{600} \cdot(S c / 600) \cdot c$

where $S c$ is the Schmidt number of methane at water surface temperature and $c$ is $-2 / 3$ for wind speeds $<3.7 \mathrm{~m} \mathrm{~s}^{-1}$ (Liss and Merlivat 1986).

\section{Bacterial abundance and FISH}

Bacterial abundance from October 2005 samples was determined by epifluorescence microscopy (Zeiss Axioscope 2, 1000 magnification) of DAPI (4',6-diamidino-2phenylindole)-stained cells. Bacterial cells were fixed by the addition of concentrated formaldehyde solution $(5 \%$ final concentration) for $15 \mathrm{~min}$ at room temperature and thereafter recovered by gentle vacuum filtration (20 and $50 \mathrm{ml}$ for each sample) onto polycarbonate filters with a 
pore size of $0.2 \mu \mathrm{m}$ (GTPB, Millipore). After washing with PBS and water, the filters were transferred into sterile PP petri dishes, sealed and stored frozen at $-20^{\circ} \mathrm{C}$ for fluorescence in situ hybridization (FISH). The protocol of Pernthaler et al. (2002) was used for the hybridization procedure. Oligonucleotide probes MG84/705 and MA450 (MWG) detecting aerobic methanotrophs (MOB) group I and II, respectively, were used to describe microbial communities. Probes were labelled with the indocarbocyanine fluorescence dye CY3 and fluorescein (MWG).

Nucleic acid extraction and RT-PCR/DGGE analysis

Water samples $(100 \mathrm{ml})$ from October 2005 were filtered through filter cartridges (Millipore Sterivex, $0.22 \mu \mathrm{m}$ pore size) and $1.8 \mathrm{ml}$ of lysis buffer was added to the filter according to Lucas et al. (2005) and stored at $-20^{\circ} \mathrm{C}$ until nucleic acids extraction. Nucleic acids were then extracted from filters according to Lucas et al. (2005). In order to identify actively growing or metabolizing microorganisms, we analyzed rRNA (Kemp et al. 1993). DNA digestion and reverse transcription of RNA to complementary DNA (cDNA) was performed according to Lucas and Hollibaugh (2001).

16S rRNA fragments of type I bacterial methanotrophs were amplified from cDNA using primers MphI-703r and 341f with GC-clamp (Table 1). PCR products were cleaned with an exonuclease I and shrimp alkaline phosphatase treatment ( 3 and $0.6 \mathrm{U}_{\mu} \mathrm{L}^{-1}$, respectively), $15 \mathrm{~min}$ at $37^{\circ} \mathrm{C}$ then $15 \mathrm{~min}$ at $85^{\circ} \mathrm{C}$. PCR reactions were conducted with $50 \mathrm{ng}$ of crude DNA, $1 \times$ Taq buffer (Qbiogen), $2.5 \mathrm{mM}$ $\mathrm{MgCl}_{2}, \quad 0.1 \mathrm{mg} \mathrm{mL}^{-1}$ BSA (final concentration), $200 \mu \mathrm{mol} \mathrm{L}{ }^{-1}$ dNTPs, $0.5 \mu \mathrm{mol} \mathrm{L}{ }^{-1}$ of each primer and $1 \mathrm{U}$ of Taq polymerase (Qbiogen). Amplification was performed using the following temperature program: $94^{\circ} \mathrm{C}$ for $5 \mathrm{~min}, 30$ cycles at $94^{\circ} \mathrm{C}$ for $30 \mathrm{~s}, \mathrm{X}^{\circ} \mathrm{C}$ (X stands for the annealing of each primer pair, Table 1$), 72^{\circ} \mathrm{C}$ for $4 \mathrm{~min}$, and finally $72^{\circ} \mathrm{C}$ for $20 \mathrm{~min}$. After $1 \%$ agarose gel electrophoresis with lambda DNA standard solutions (Promega), PCR products were quantified using the software ImageJ (Rasband 1997-2005).

Amplified products were separated by DGGE using a Bio-Rad D-Code system. Polyacrylamide gels $(6 \%$ (wt/vol) acrylamide $/ N, N^{\prime}$-methylene bisacrylamide ratio, 37:1 [w/ w]) contained a linear 30-65\% gradient of denaturant
(100\% denaturant $=7 \mathrm{~mol} \mathrm{~L}^{-1}$ urea plus $40 \% \quad[\mathrm{v} / \mathrm{v}]$ formamide). Electrophoresis was performed for $15 \mathrm{~h}$ at $70 \mathrm{~V}$ and $60^{\circ} \mathrm{C}$. Gels were stained $20 \mathrm{~min}$ with ethidium bromide ( $1 \mathrm{ng} \mathrm{mL}^{-1}$ final concentration) and washed 20 min with distilled water, then visualised under UVlight.

\section{Sequencing of DGGE bands}

Bands containing sufficient quantities of cDNA were excised from the gel and were frozen at $-20^{\circ} \mathrm{C}$ for $1 \mathrm{~h}$. cDNA was eluted in $60 \mu \mathrm{l}$ of water at $55^{\circ} \mathrm{C}$ for $2 \mathrm{~h}$ and was amplified following the PCR conditions described above, using the same primer pairs but without GC clamp. The PCR products were cleaned with an exonuclease I and shrimp alkaline phosphatase treatment as described above. The sequences were obtained from an automated sequencer CEQ 8000 (Beckman Coulter) using the QuickStart premix. All band sequences between 270 and 400 bp were submitted to GenBank (Accession numbers GU048509 to GU048520).

\section{Results and discussion}

\section{A 1-year cycle}

Figure 1 displays the oxygen concentration recorded monthly in 2007 showing clearly the fully mixed water column in winter/spring and the slow build-up of a stratified water column over summer and fall. Besides oxygen, two parameters (the concentration and the carbon isotopic composition of methane) were used to describe methane related processes in the water column. The carbon isotopic composition of methane was applied in this study to determine (1) the source of methane, (2) the location at which methane was oxidized, and (3) to rule out mixing of water masses as an explanation for the observed methane concentration profiles. Microbially mediated oxidation of methane is clearly visible in the carbon isotopic composition (and/or in the hydrogen isotopic composition) since it is accompanied by a strong isotope fractionation. The isotopically "lighter" methane is more rapidly oxidized leaving behind methane with a "heavier" isotopic signature (Barker and Fritz 1981). The carbon isotopic signature
Table 1 Primers pairs and annealing temperature used for the PCR and hybridization conditions

A GC clamp (Muyzer et al. 1993) was added to primer $341 \mathrm{f}$

\begin{tabular}{lllll}
\hline Organisms & $\begin{array}{l}\text { Primer } \\
\text { pairs }\end{array}$ & $\begin{array}{l}\text { Temp. } \\
\left({ }^{\circ} \mathrm{C}\right)\end{array}$ & $\begin{array}{l}\text { Formamide } \\
(\text { conc. \%) }\end{array}$ & Reference \\
\hline Type I MOB & $\begin{array}{l}341 \mathrm{f}- \\
\text { MphI-703r }\end{array}$ & 55 & 20 & $\begin{array}{l}\text { Muyzer et al. (1993) } \\
\text { Coolen et al. (2004) } \\
\text { Type II MOB }\end{array}$ \\
\hline
\end{tabular}



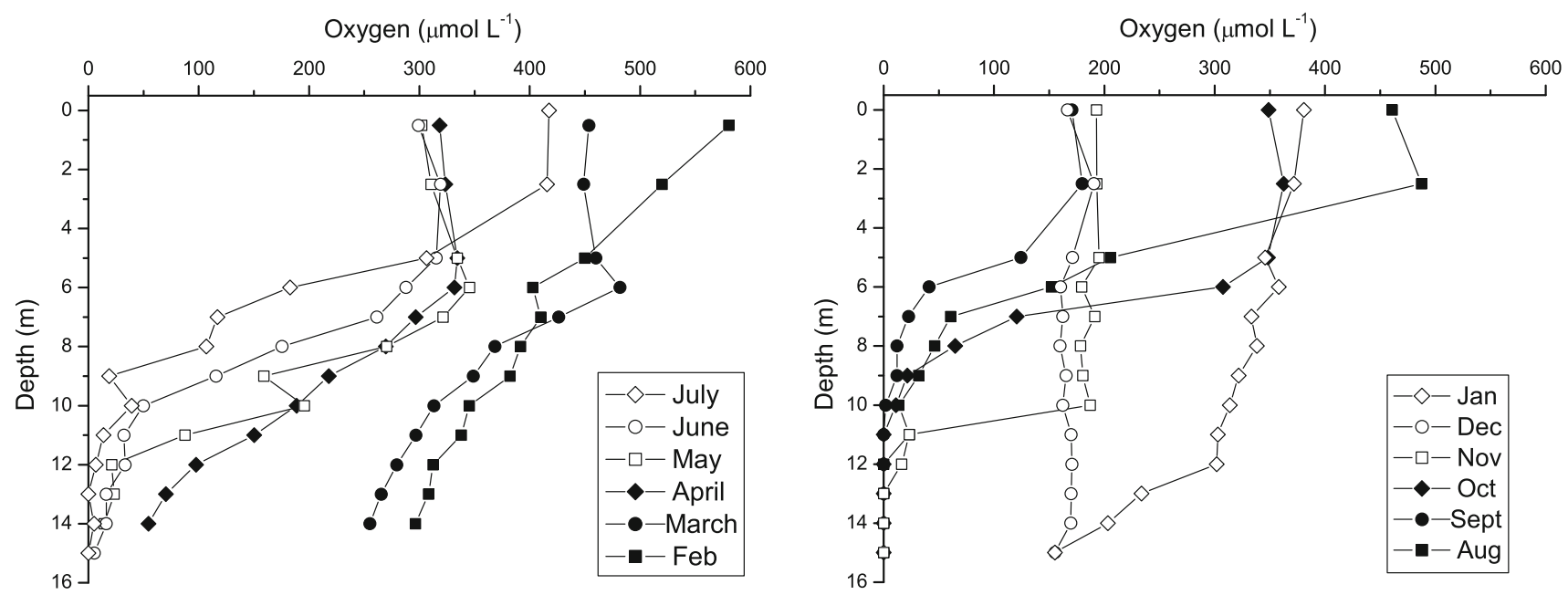

Fig. 1 Oxygen concentrations in $\mu \mathrm{mol} \mathrm{L}{ }^{-1}$ measured in Lake Rotsee over a full year (2007)

of methane also points to its way of formation, i.e., either abiotic (isotopically heavy) or biogenic (isotopically light) (Schoell 1988). Since the carbon isotopic composition of the dissolved methane close to its source, namely sediments, was very light $(-70 \%)$, a biological formation is inferred. Support for this assumption also comes from incubation studies in which both biological methanogenic pathways, i.e., carbon reduction and fermentation were identified (Zepp Falz et al. 1999). In December/January, when the lake was not stratified, i.e. the water column was fully mixed, the carbon isotopic composition of the dissolved methane $\left(\delta^{13} \mathrm{C}_{\text {methane }}\right)$ was around -20 to $-30 \%$ (Fig. 2a). In February, the $\delta^{13} \mathrm{C}_{\text {methane }}$ close to the lake bottom was $-12 \%$ indicating that the methane present at this time of year is the remainder of a once much larger reservoir that was microbially oxidized (Fig. 2b). In the surface layer $(0-2.5 \mathrm{~m}), \delta^{13} \mathrm{C}_{\text {methane }}$ was between -42.7 and $-38.6 \%$. This value, which was much lighter than during lake-overturn, indicates a different origin of methane than that in the deep water and points to lateral transport from littoral sediments (Bussmann 2005; Murase et al. 2005). Little oxygen had been consumed by degradation of organic material $(\mathrm{OM})$ at the bottom of the lake that was either left over from last year or already newly produced. Mineralization in the sediment was indicated by an increase of $\mathrm{NH}_{4}$ just above the lake floor due to diffusion from sediments (Fig. 3d). Due to the presence of oxygen in the water column, $\mathrm{NO}_{3}{ }^{-}$and $\mathrm{SO}_{4}{ }^{2-}$ were not yet used for degradation of OM. Instead, $\mathrm{SO}_{4}{ }^{2-}$ concentrations were enhanced close to the sediment surface due to sulphide oxidation. Sulphide oxidation by phototrophic sulphur bacteria in the chemocline was described by Kohler et al. (1984) later in the year, but it is very likely that early in the year, i.e. now in February, this oxidation occurs close to the sediment since the sulphide diffuses out of the sediment and has not yet accumulated in the water column.

In March, methane concentrations $(0.10-0.26 \mu \mathrm{M})$ were on average already 4 times higher than in February and a clear differentiation into hypolimnion and epilimnion was visible (Fig. 2b). Below $9 \mathrm{~m}$, the $\delta^{13} \mathrm{C}_{\text {methane was on }}$ average around $-25 \%$ indicating that the methane in the deep water consisted of the remains of a formerly large reservoir that was microbially oxidized. No newly produced methane, which would have a $\delta^{13} \mathrm{C}_{\text {methane }}$ of below $-70 \%$ (see discussion on May data), was observed in the deeper water column. In contrast, $\delta^{13} \mathrm{C}_{\text {methane }}$ above $8 \mathrm{~m}$ $(-52 \%)$ clearly indicated a mixing of newly produced methane from the littoral zones and methane with a heavy $\delta^{13} \mathrm{C}_{\text {methane }}(-25 \%)$ from below $9 \mathrm{~m}$ and maybe even some atmospheric methane $(-47 \%$, Stevens and Wahlen 2000). Consumption of oxygen took place below 6-8 m due to nitrification while ammonium increased almost linearly towards the bottom of the lake. Sulphate was very well-mixed without any gradient over the water column.

In April, methane concentrations $\left(0.24-0.75 \mu \mathrm{mol} \mathrm{L}^{-1}\right)$ had about doubled and the $\delta^{13} \mathrm{C}_{\text {methane }}$ was on average $10 \%$ lighter (Fig. 2b). Due to a very warm spring in 2007, an extreme algal bloom had built up and the OM settling to the lake bottom triggered low oxygen and decreasing nitrate concentrations below $13 \mathrm{~m}$. These suboxic conditions in the water column and anoxic conditions in the sediments opened the possibility to fully express OM degradation via methanogenesis. This gave rise to an over 40 times increase in methane concentration (0.3$54 \mu \mathrm{mol} \mathrm{L}{ }^{-1}$ ) in the deep water in May and strong oxygen depletion below $8 \mathrm{~m}$ (Figs. 1a, 2c). Maximum oxygen and nitrate consumption occurred at $12 \mathrm{~m}$ depth, whereas 

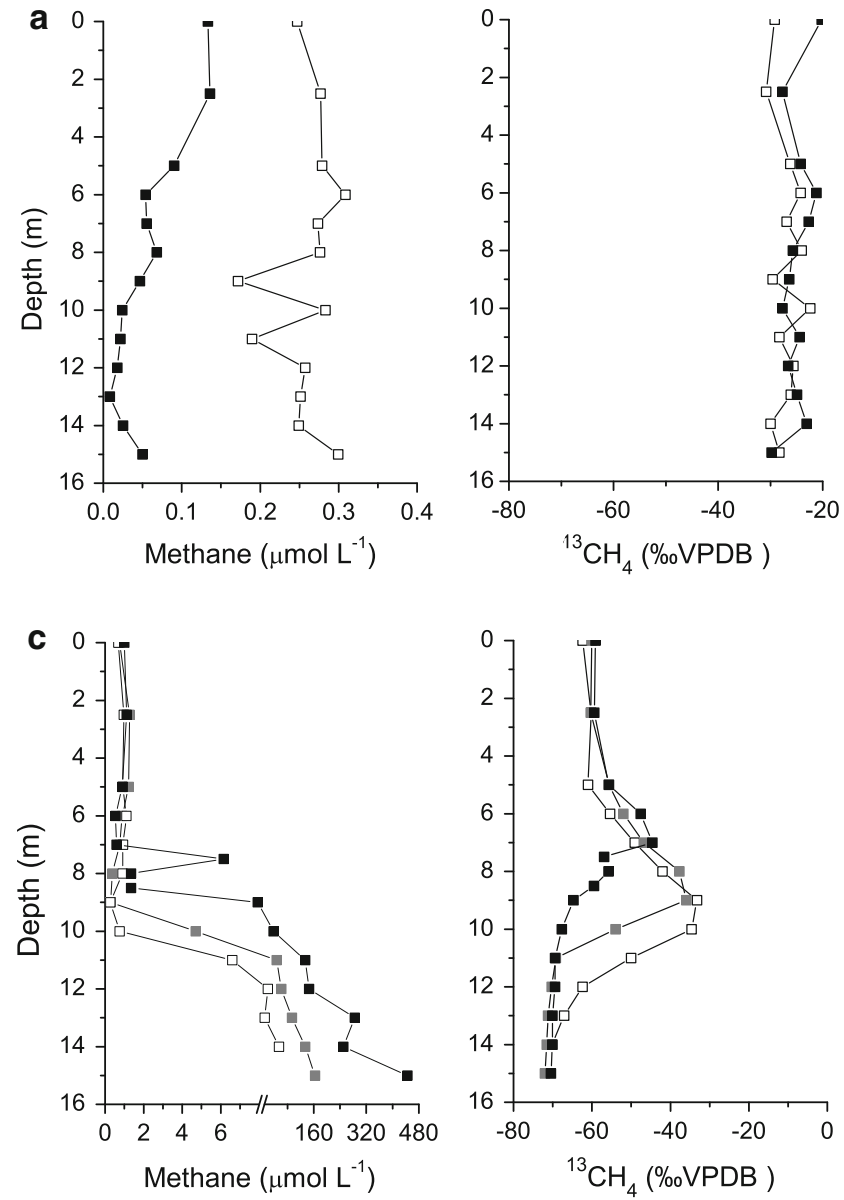

Fig. 2 Methane concentration (left) and carbon isotopic composition of methane (right) over a full year in Lake Rotsee. a December (open squares) and January (black squares), b February (open squares),

sulphate was not taking part in the redox processes at the depth of the chemocline (Fig. 3). In contrast, maximum sulphate consumption took place right above the sediment. That sulphate reduction was highest close to and in the sediments and not in the water column around the chemocline was described already by Kohler et al. (1984). Additionally, a strong change in $\delta^{13} \mathrm{C}_{\text {methane }}$ was observed in the deep water. For the first time, the large methane input from the sediments was visible by increasing methane concentrations towards the sediment with $54 \mu \mathrm{mol} \mathrm{L}{ }^{-1}$ methane in the water overlying the sediment and very light $\delta^{13} \mathrm{C}_{\text {methane }}$ (down to $-70 \%$ ).

With respect to methane, different sources can be characterized for the epi- and hypolimnion. The former was supplied by the small amount of lateral methane input from the littoral zone, and the latter was dominated by the very high methane contribution from the sediments where methanogenesis occurred. Additionally, the profile showed very heavy $\delta^{13} \mathrm{C}_{\text {methane }}$ values $(-33.2 \%$ ) and very low methane concentrations (down to $268 \mathrm{nM}$ ) at 9 and $10 \mathrm{~m}$,
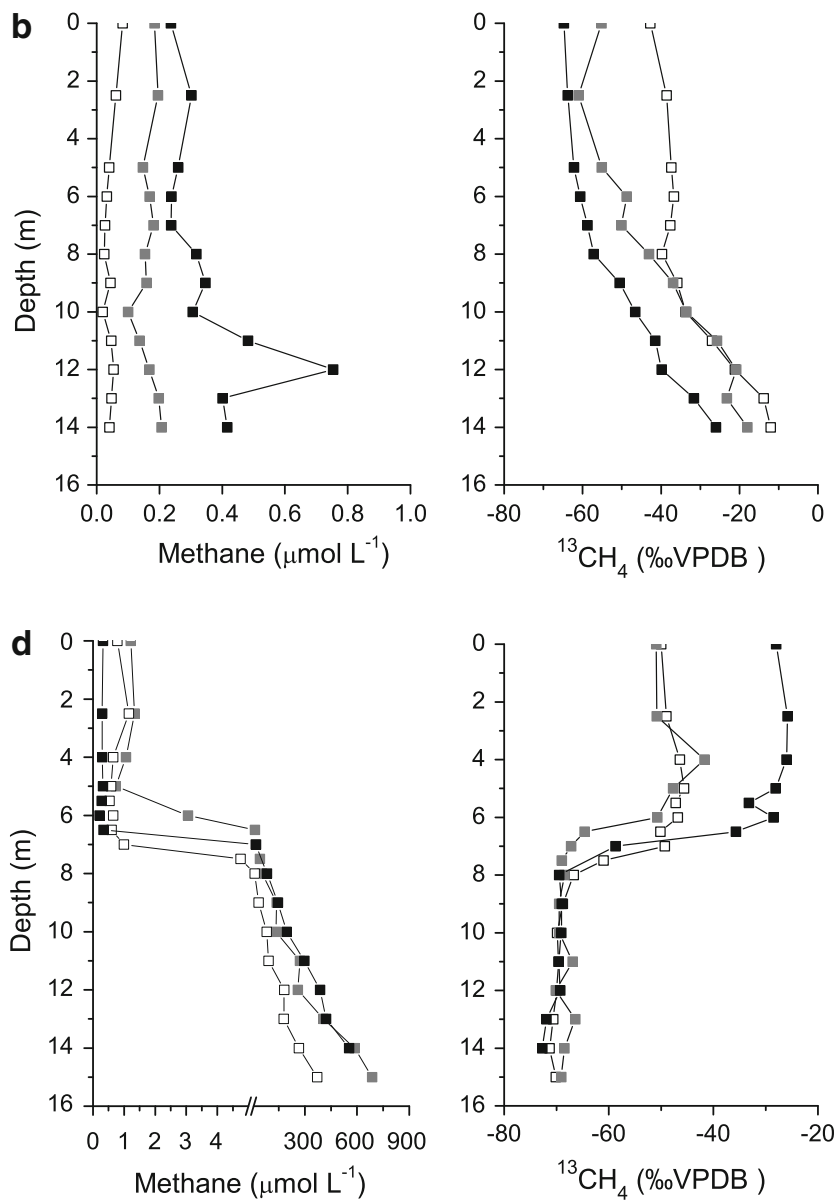

March (grey squares), and April (black squares), c May (open squares), June (grey squares), July (black squares), d August (open squares), September (grey squares), and October (black squares)

indicating that a microbial community occurred in this layer mediating methane oxidation.

In the following months (June to November), methane concentrations increased compared to the previous month as follows: 4 times in June, 2 times in July, September, and November (Fig. 2c, d). Methane concentrations remained approximately constant from July to August and from September to October. The depth of maximum methane consumption matched with the location of maximum consumption of oxygen and nitrate in all months (Fig. 3). Interestingly, the profiles of oxygen and ammonium always overlapped by $2-4 \mathrm{~m}$, suggesting that the oxidation of ammonium was slower than its vertical transport in the water column (Figs. 1a, b, 3). Sulphate was mainly consumed directly above the sediment and was therefore not involved in processes occurring in the chemocline (Fig. 3). However, later in the year starting with September, the zone of sulphate reduction moved closer to the chemocline and sulphate seemed to be involved in the redox cycle in this zone. Hence, we 

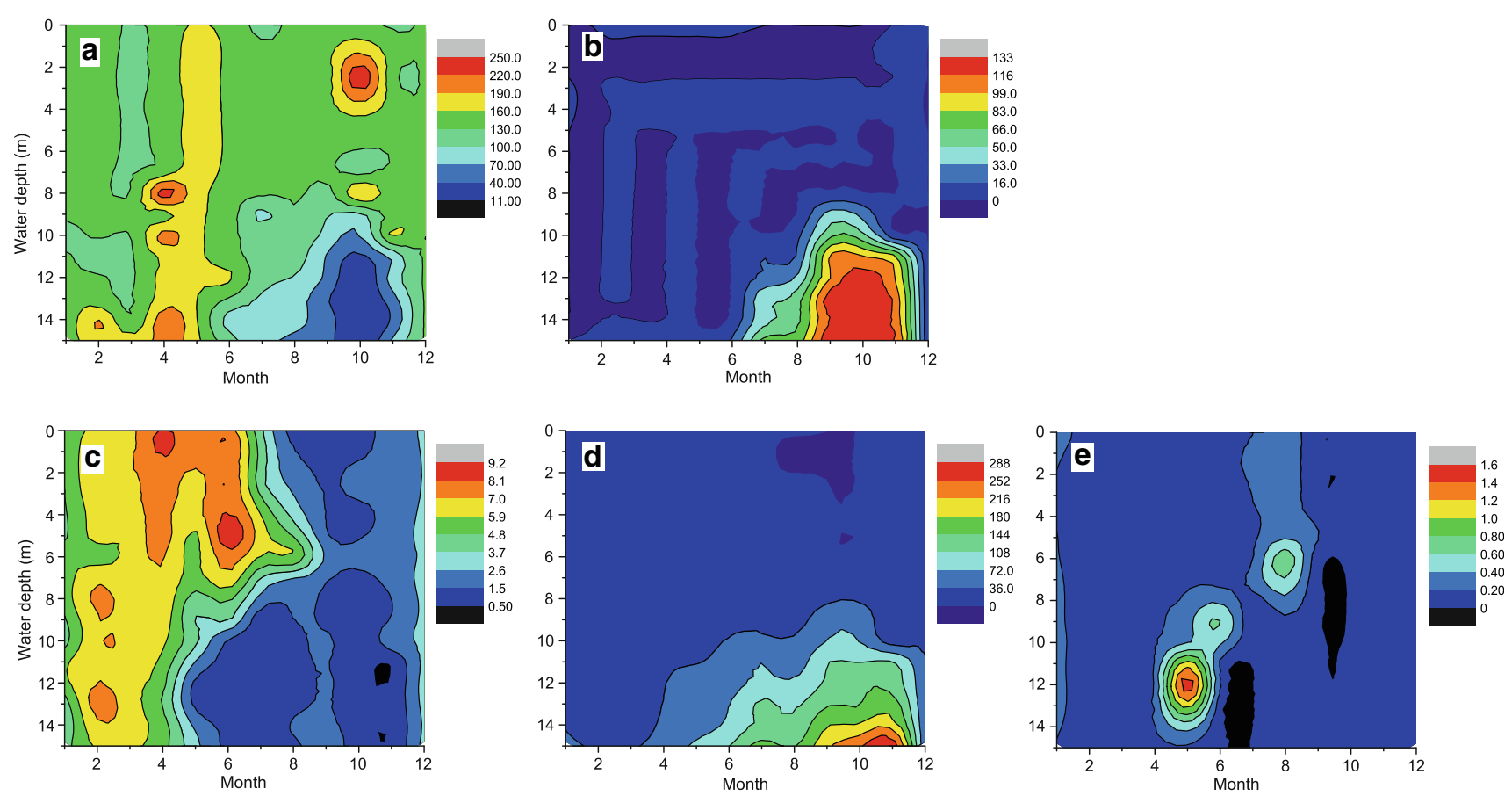

Fig. 3 Concentrations in $\mu \mathrm{mol} \mathrm{L}{ }^{-1}$ of sulphate $\mathbf{a}$, sulphide $\mathbf{b}$, nitrate $\mathbf{c}$, ammonium d, nitrite $\mathbf{e}$ in the water column over the year (2007) in Lake Rotsee

conclude that at the spatial resolution available, we could not detect a possible partial interaction of methane oxidation and sulphate reduction except for the end of the stratification period.

It is obvious that the flux of electrons calculated from the transformation of oxidants and reductants is well-balanced between electron acceptors and donors. This is shown in Fig. 4 where the flux of electrons (in mmol $\mathrm{e}^{-} \mathrm{m}^{-2}$ day $^{-1}$ ) due to oxidizing reactions is plotted in positive numbers, and the flux from reducing reactions in negative numbers. In June at $10 \mathrm{~m}$ depth, the electron flux caused by the consumption of oxygen and nitrate (32.7 $\mathrm{mmol} \mathrm{e}^{-} \mathrm{m}^{-2} \mathrm{day}^{-1}$ ) almost exactly matched the electron flux from methane, sulphide, and ammonium oxidation $\left(32.8 \mathrm{mmol} \mathrm{e}^{-} \mathrm{m}^{-2} \mathrm{day}^{-1}\right.$ ). Sulphate reduction, however, occurred directly at the sediment surface and was not involved in methane oxidation (Fig. 3). The same is true for July when maximum oxygen and nitrate consumption occurred at around $9 \mathrm{~m}$ depth (Fig. 3). Fluxes of oxygen plus nitrate $\left(46.0 \mathrm{mmol} \mathrm{e}^{-} \mathrm{m}^{-2} \mathrm{day}^{-1}\right)$ matched the flux of reductants $\left(52.0 \mathrm{mmol} \mathrm{e}^{-} \mathrm{m}^{-2} \mathrm{day}^{-1}\right.$, Fig. 4). Sulphate was still only depleted at greater depth and seemed not to be involved in methane oxidation. It must be stated, however, that the separation of zones of methane oxidation in the water column and sulphate reduction at the sediment surface does not exclude AOM because this process might still have occurred in the upper sediment layer and sediment-water interface where methane is released into the water column.

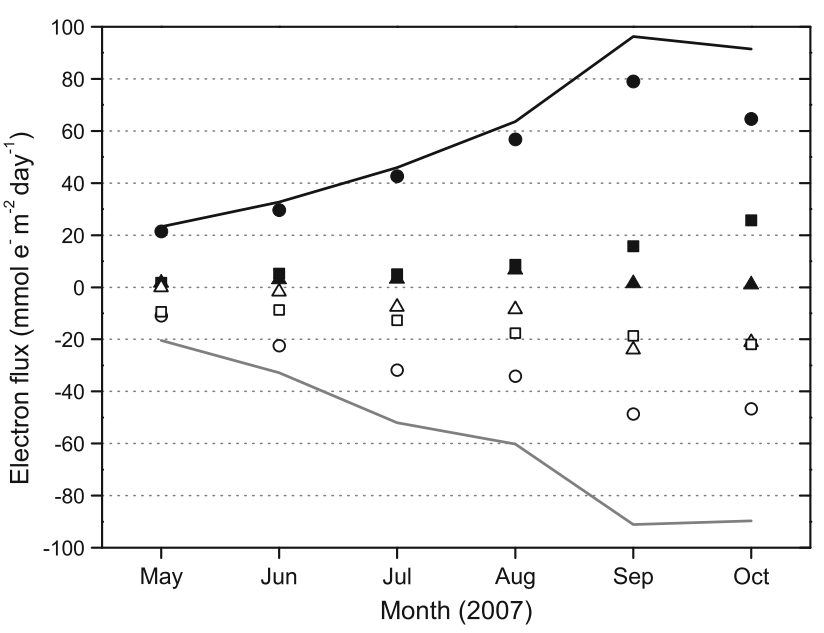

Fig. 4 Fluxes of electrons in the water column of Lake Rotsee calculated from fluxes of the oxidants oxygen (black circles), nitrate (black triangles), sulphate (black squares), and the reductants methane (open circles), ammonium (open triangles), and sulphide (open squares). The black and grey lines are the sum of the oxidants (including sulphate only in September and October, see text for explanation) and reductants, respectively. The fluxes cover the time of stable lake stratification when transport could be attributed to turbulent diffusion and hence calculation of $k z$ values was possible

Since the flux of sulphate was very low $(5 \mathrm{mmol}$ $\mathrm{e}^{-} \mathrm{m}^{-2}$ day $^{-1}$ ) compared to the methane flux of $32 \mathrm{mmol} \mathrm{e}^{-} \mathrm{m}^{-2}$ day $^{-1}$, AOM via sulphate would not leave a signal in the $\delta^{13} \mathrm{C}_{\text {methane, }}$, which is only visible after a large fraction of the methane is oxidized. 
The zone of interaction between oxygen, nitrate, and methane, sulphide and ammonium moved about $1 \mathrm{~m}$ deeper in August, with well balanced reaction rates of 63.6 and $60.2 \mathrm{mmol} \mathrm{e}^{-} \mathrm{m}^{-2} \mathrm{~d}^{-2}$, respectively (Figs. 3, 4).

In September, methane was oxidized at 6-7 m (Fig. 2d) and oxygen was most likely the oxidant. A bend in the methane concentration profile at $12 \mathrm{~m}$, however, suggested that part of the methane was consumed in this zone. At the same depth, the sulphate concentration profile also showed a sharp bend. Unfortunately, the spatial resolution of the concentration profiles was not good enough to accurately determine the fluxes. A best estimate leads to a sulphate electron flux of $15.7 \mathrm{mmol} \mathrm{e}^{-} \mathrm{m}^{-2}$ day $^{-1}$ compared to an electron flux of $48.6 \mathrm{mmol} \mathrm{e}^{-} \mathrm{m}^{-2}$ day ${ }^{-1}$ for methane in this zone. Hence, only one-third of the electron transfer during methane oxidation could be attributed to the reduction of sulphate. The same spatial pattern was observed in October, and we therefore included sulphate into the sum of oxidants and accordingly a well-balanced electron flux between electron donors and acceptors was observed in September and October (Fig. 4). The situation in October is comparable in that maximum sulphate consumption occurred more than $2 \mathrm{~m}$ above the sediment (between 11 and $12 \mathrm{~m}$ ) with a flux of $25.7 \mathrm{mmol} \mathrm{e}^{-} \mathrm{m}^{-2}$ day $^{-1}$ and a local flux of methane of $46.7 \mathrm{mmol} \mathrm{e}^{-} \mathrm{m}^{-2}$ day $^{-1}$; i.e. a little more than $55 \%$ of the methane could have been oxidized with sulphate and other oxidants such as nitrate and maybe iron and manganese, as discussed recently by Beal et al. (2009) in the marine environment, were needed for a more complete oxidation.

In early November, highest methane concentrations were measured with $1.1 \mathrm{mmol} \mathrm{L}^{-1}$ in the bottom waters as a result of the high productivity in the summer months (Fig. 6).

\section{Winter overturn}

Seasonally stratified lakes often turn over in late fall when atmospheric temperatures decrease and stronger winds bring in mixing energy (Wetzel 1983). This was observed in Lake Rotsee between the sampling in October and November where the chemocline shifted from $7 \mathrm{~m}$ down to $11 \mathrm{~m}$ (Fig. 1b). In November 2007, two profiles were taken on the 7 th and again on the 15 th after a strong storm on the 10 th and 11th of November. After this storm, the lake was mixed down to $14 \mathrm{~m}$ as seen in the straight oxygen and temperature profiles (Fig. 5). Whereas this was also clearly visible in the methane concentration profiles of both days, it was even more pronounced in the $\delta^{13} \mathrm{C}_{\text {methane of meth- }}$ ane, which showed a marked increase in the fraction of heavy isotopes in the remaining methane $(-30 \%$ throughout the whole water column, Fig. 6). This very heavy $\delta^{13} \mathrm{C}_{\text {methane }}$ indicates that methane was oxidized since there was no isotopically heavy methane available to produce a corresponding mixing signal. The above mentioned pattern prevailed throughout December with methane concentrations below $0.3 \mu \mathrm{M}$, and in January with
Fig. 5 Oxygen concentrations (black line) and temperature (grey line) on the 7 th and 15 th of November. Between both dates a storm occurred resulting in a mixing down to $14 \mathrm{~m}$
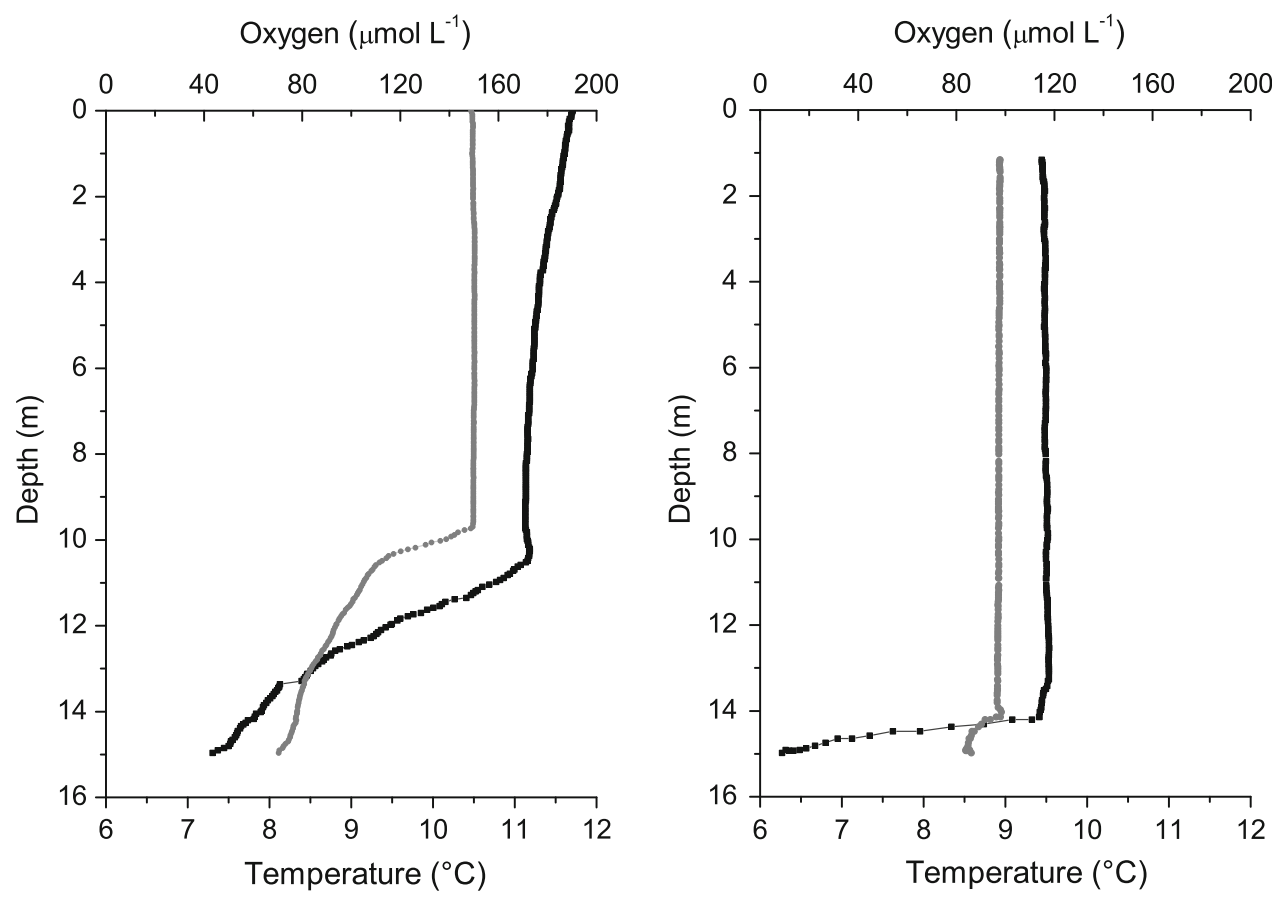
Fig. 6 Methane concentrations and carbon isotopic composition of methane on the 7th (left) and 15 th of November (right) showing the strong mixing of the lake resulting in strongly oxidized methane ( $\delta$ values of $-30 \%$ ) throughout the water column

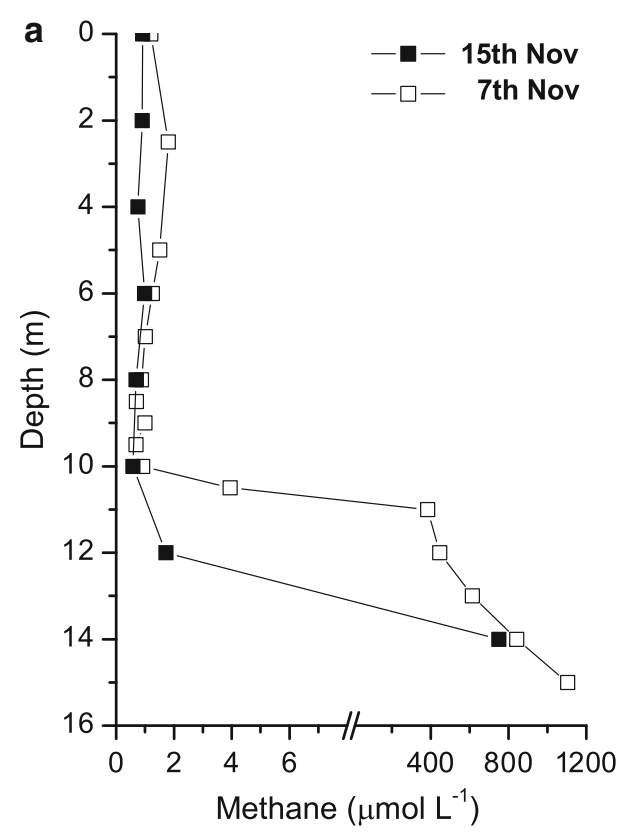

methane concentrations below $0.1 \mu \mathrm{M}$. In both months, the dissolved methane had very heavy $\delta^{13} \mathrm{C}_{\text {methane }}$ of around $-25 \%$ o (Fig. 2a).

Surface water methane concentrations and methane emissions

The concentration of methane in the surface water, which is in thermodynamic equilibrium with the atmosphere (according to the Henry coefficient), should be approximately $2 \mathrm{nmol} \mathrm{L}^{-1}$. However, Fig. 7 shows that throughout the whole year methane concentrations were well above this value. They were at minimum 40 times higher (February, $80 \mathrm{nM}$ ) and up to 600 times higher in November $(1,200 \mathrm{nM})$, demonstrating that the surface water of Lake Rotsee was always oversaturated and, therefore, a source of methane to the atmosphere. This holds true for all lakes and reservoirs in Switzerland that we have investigated over the last 5 years (Diem et al. 2008). Methane emission values calculated from the boundary layer model using the formula by Cole and Caraco (1998) were two times higher than values derived using the formula from Crusius and Wanninkhof (2003) and varied therefore from 0.2 to $0.4 \mathrm{mg} \mathrm{CH}_{4} \mathrm{~m}^{-2}$ day $^{-1}$ in February, 3.0 to $6.8 \mathrm{mg} \mathrm{CH}_{4}$ $\mathrm{m}^{-2}$ day $^{-1}$ in June and 3.2 to $7 \mathrm{mg} \mathrm{CH}_{4} \mathrm{~m}^{-2}$ day $^{-1}$ in November (Table 2). Annual emissions based on these numbers were estimated to be between 73 and 2,600 $\mathrm{mg} \mathrm{CH}_{4} \mathrm{~m}^{-2}$. Comparing this number to the possible emission of methane $\left(5 \mathrm{~g} \mathrm{~m}^{-2} \mathrm{day}^{-1}\right)$, assuming that all methane stored in the hypolimnion would be released, shows that the bacterial community was very effective in oxidizing methane.

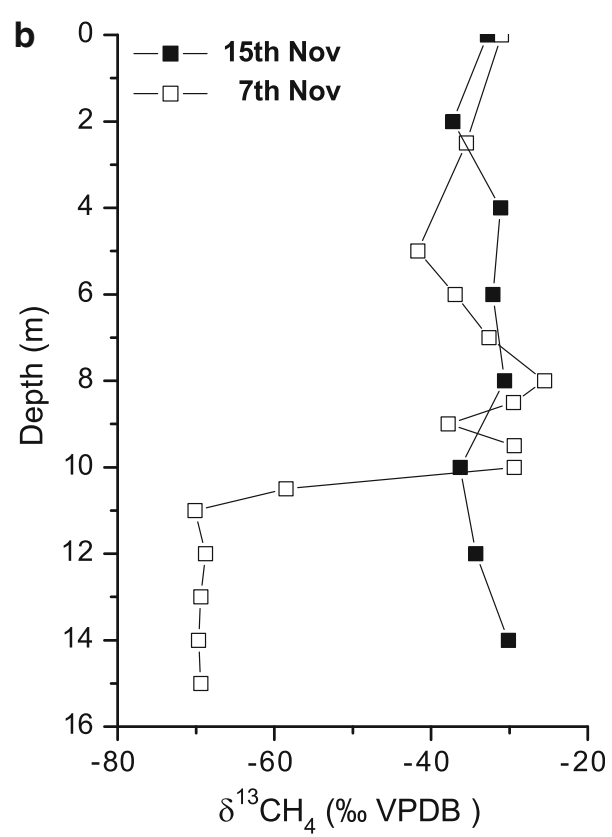

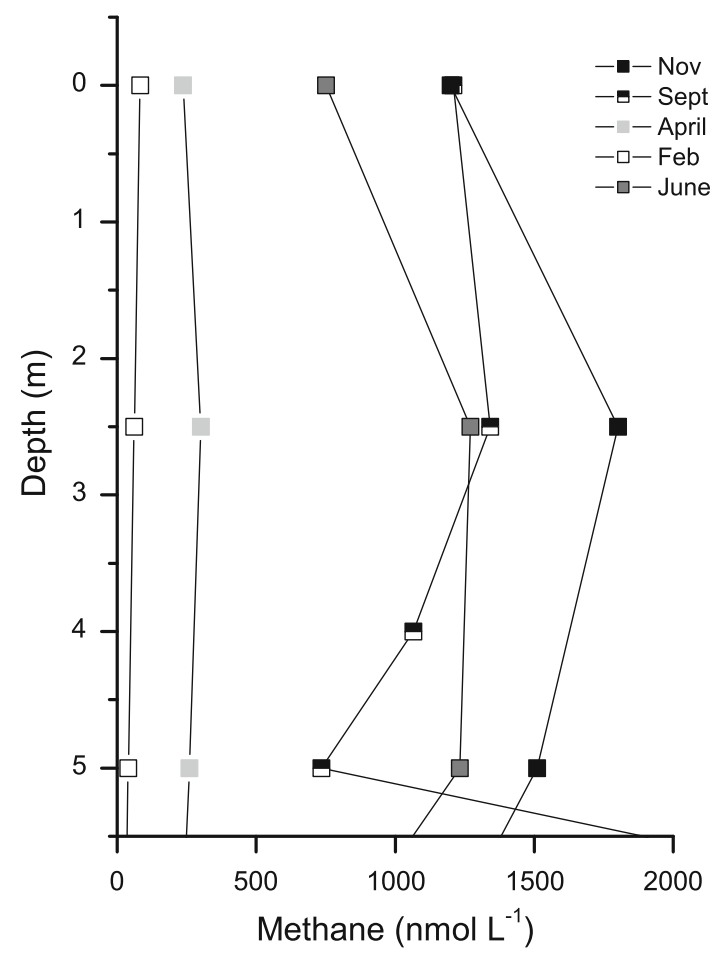

Fig. 7 Methane concentrations of the upper water column $(0-5 \mathrm{~m})$ showing strong oversaturation of methane (equilibrium concentration with atmosphere would be approximately $2 \mathrm{nmol} \mathrm{L}^{-1}$ )

Organisms involved in methane oxidation

DAPI staining revealed bacterial numbers between 2 and $6 \times 10^{6} \mathrm{ml}^{-1}$ in the water column of Lake Rotsee. In October 2005, methane oxidation peaked in the zone where 
Table 2 Methane emissions in $\mathrm{mg} \mathrm{m}^{-2} \mathrm{day}^{-1}$ calculated using the transfer velocity $k_{600}$ from Cole and Caraco (1998) and Crusius and Wanninkhof (2003)

\begin{tabular}{llllr}
\hline Month & $\begin{array}{l}\text { Emissions }\left(\mathrm{mg} \mathrm{m}^{-2} \mathrm{day}^{-1}\right) \\
\text { Cole and Caraco }(1998)\end{array}$ & $\begin{array}{l}\text { Emissions }\left(\mathrm{mg} \mathrm{m}^{-2} \text { day }^{-1}\right) \\
\text { Crusius and Wanninkhof }(2003)\end{array}$ & Wind speed $\left(\mathrm{m} \mathrm{s}^{-1}\right)$ & Water temp. $\left({ }^{\circ} \mathrm{C}\right)$ \\
\hline February & 0.4 & 0.2 & 0.9 & 5.6 \\
June & 6.8 & 3.0 & 0.9 & 22.2 \\
November & 7.0 & 3.2 & 0.7 & 10.5 \\
\hline
\end{tabular}

Wind speeds are average values from a nearby station from the years 1981-2001 of which we substracted $0.5 \mathrm{~m} \mathrm{~s}^{-1}$ since the location of Lake Rotsee is especially wind-shielded

Fig. 8 Depth profiles of chemical and microbial parameters in October 2005. a Oxygen (filled squares), sulphate (open circles) and methane concentrations (open triangles). b Proportion of MOB type I on total DAPI stained cells (hatched bars) and methane oxidation rates (filled circles)
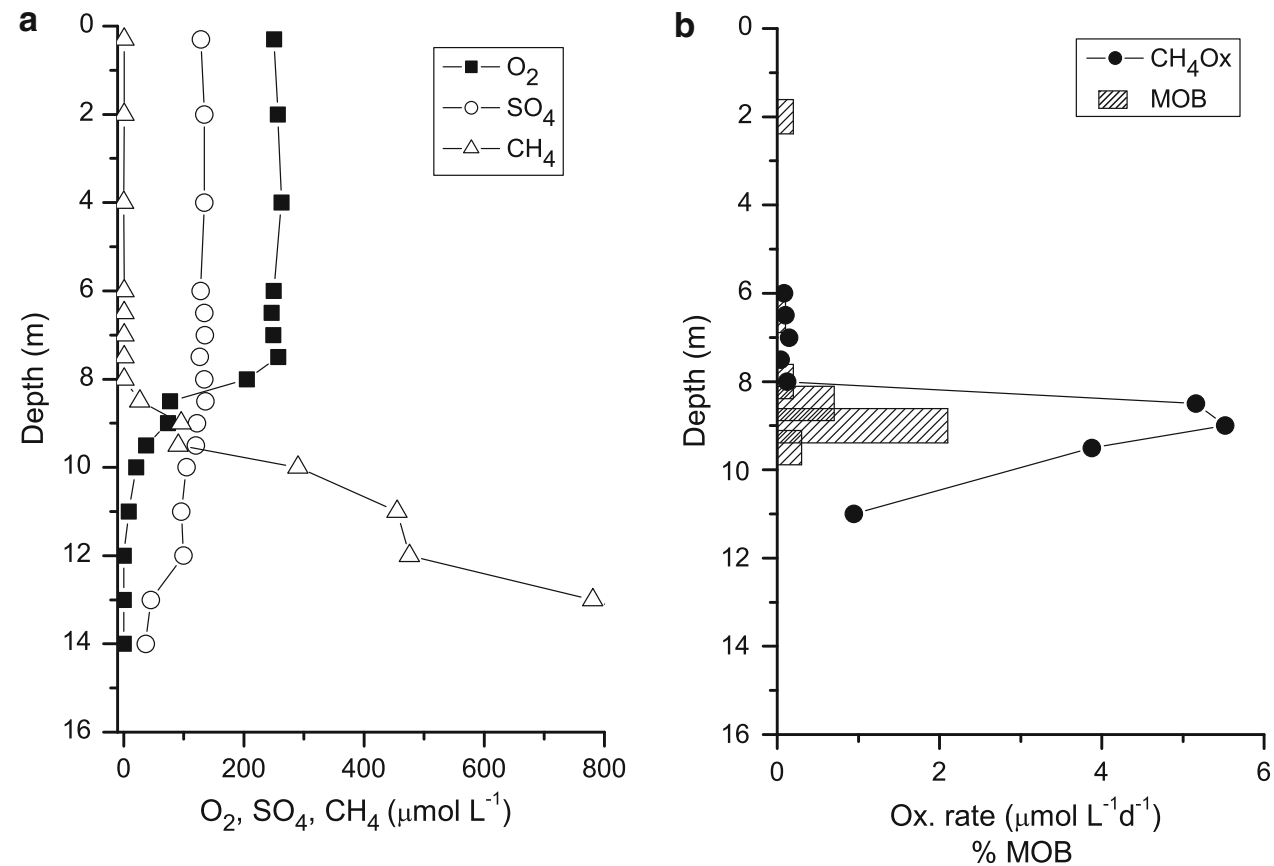

oxygen was strongly decreasing, reaching $5 \mu \mathrm{mol} \mathrm{L} \mathrm{L}^{-1}$ day $^{-1}$ at $8.5-9 \mathrm{~m}$ (Fig. 8). This result was supported by a high proportion of type I methane oxidizing bacteria (MOB) at $9 \mathrm{~m} \mathrm{(2 \%} \mathrm{of} \mathrm{total} \mathrm{DAPI} \mathrm{counts,} \mathrm{Fig.} \mathrm{8).} \mathrm{MOB} \mathrm{are} \mathrm{often}$ located in a narrow zone within the chemocline where oxygen is low (Fenchel and Blackburn 1979) and it seems that higher oxygen concentrations in lakes can even limit methane oxidation (Rudd and Hamilton 1975). Aerobic methanotrophs were dominated by type I group $(\gamma$-Proteobacteria) and no type II MOB could be detected by FISH. Although the type I dominance is not universal in freshwater bodies, it has been reported for example in temperate lakes, lake Constance, and the Black Sea (Sundh et al. 2005; Schubert et al. 2006; Rahalkar et al. 2009). DGGE analysis showed a low diversity in this group and the bands present at 9 (strong), $9.5 \mathrm{~m}$ (very strong), and $10 \mathrm{~m}$ (weak) were identified as a type I MOB with its $16 \mathrm{~S}$ rRNA gene sequence 98.4\% similar to the sequence of the clone C5LKS3 and $97.1 \%$ to the sequence of Methylomonas rubra.

\section{Conclusions}

In a full year's cycle of Lake Rotsee, we observed the release of large amounts of biogenic methane from the sediments to the lower anoxic water column reaching concentrations $>1 \mathrm{mmol} \mathrm{L}^{-1}$ before the winter turn-over. Without oxidation in the water column, the full content of about $1,700 \mathrm{t} \mathrm{CH}_{4}$ could be released during turnover from the hypolimnion. However, due to the activity of aerobic methane oxidizing bacteria (MOB Type I, closely related to Methylomonas) and most likely anaerobic microorganisms (so far not yet identified), this amount is much lower and on average only $2.3 \mathrm{mg} \mathrm{CH}_{4} \mathrm{~m}^{-2}$ day $^{-1}$ (range 0.2 $7 \mathrm{mg} \mathrm{CH}_{4} \mathrm{~m}^{-2} \mathrm{day}^{-1}$ ) or $0.8 \mathrm{t} \mathrm{year}^{-1}$ are released. The electron balance between oxidizing and reducing process rates in the water column is well-adjusted, indicating that all relevant processes in this system are covered. Interestingly enough, sinking organic particles do not seem to play a significant role as reducing agents in the water column, 
since the electron balance is well-equilibrated taking all reducing (methane, ammonium, and sulphide) and oxidizing (oxygen, nitrate, and sulphate) reagents into account. Once settled to the sediments, the particulate organic material serves as an electron donor for sulphate reduction. Considering the electron balance, we conclude that methane is both aerobically and anaerobically oxidized in the water column of Lake Rotsee. However, the question of which species are involved in methane oxidation could not be solved completely. Whereas sulphate might play a role in methane oxidation later in the year, this seems not to be the case earlier in the year since sulphate reduction and AOM are taking place at different locations. Additionally, also later in the year, sulphate concentrations are not sufficient to explain the oxidation of the entire methane pool and other electron acceptors need to be involved. Whether those are nitrate as proposed by Raghoebarsing et al. (2006) and Ettwig et al. (2008) or iron and/or manganese minerals as proposed by Beal et al. (2009) needs further research.

Acknowledgments We are grateful to two dedicated reviewers that helped improve the manuscript. Martin Schmid is acknowledged for the estimation of eddy diffusion coefficients, Michael Schurter is thanked for help during field work and Esther Aquilar for FISH analysis. Alfred Wüest is thanked for letting us work in silence and taking away the administrative burden. Funding was provided by internal Eawag funds.

\section{References}

Barker JF, Fritz P (1981) Carbon isotopic fractionation during microbial methane oxidation. Nature 293:289-291

Bastviken D, Cole J, Pace M, Tranvik L (2004) Methane emissions from lakes: dependence of lake characteristics, two regional assessments, and a global estimate. Global Biogeochem Cycles 18:GB4009. doi:10.1029/2004GB002238

Beal EJ, House CH, Orphan VJ (2009) Manganese- and irondependent marine methane oxidation. Science 325:184-187

Boetius A, Ravenschlag K, Schubert CJ, Rickert D, Widdel F, Gieseke A, Amann R, Jørgensen BB, Witte U, Pfannkuche O (2000) A marine microbial consortium apparently mediating anaerobic oxidation of methane. Nature 407:623-626

Bourne DG, Holmes AJ, Iversen N, Murrell C (2000) Fluorescent oligonucleotide rDNA probes for specific detection of methane oxidising bacteria. FEMS Microb Ecol 31:29-38

Bussmann I (2005) Methane release through resuspension of littoral sediment. Biogeochemistry 74:283-302

Cicerone RJ, Oremland RS (1988) Biogeochemical aspects of atmospheric methane. Global Biogeochem Cycles 2:299-327

Cole JJ, Caraco NF (1998) Atmospheric exchange of carbon dioxide in a low-wind oligotrophic lake measured by the addition of SF6. Limnol Oceanogr 43:647-656

Conrad R (1989) Control of methane production in terrestrial ecosystems. In: Andreae MO, Schimel DS (eds) Exchange of trace gases between terrestrial ecosystems and the atmosphere. Dahlem Konferenzen, Wiley, Chichester, pp 39-58

Coolen MJL, Hopmans EC, Rijpstra WIC, Muyzer G, Schouten S, Volkman JK, Sinninghe Damste JS (2004) Evolution of the methane cycle in Ace Lake (Antarctica) during the Holocene: response of methanogens and methanotrophs to environmental change. Org Geochem 35:1151-1167

Crusius J, Wanninkhof R (2003) Gas transfer velocities measured at low wind speed over a lake. Limnol Oceanogr 48:1010-1017

DEW (2004) Deutsche Einheitsverfahren zur Wasseruntersuchung. Wiley-VCH, New York

Dickens GR (2003) Rethinking the global carbon cycle with a large, dynamic and microbially mediated gas hydrate capacitor. Earth Planet Sci Lett 213:169-183

Diem T, Koch S, Schwarzenbach S, Wehrli B, Schubert CJ (2008) Greenhouse gas emissions $\left(\mathrm{CO}_{2}, \mathrm{~N}_{2} \mathrm{O}, \mathrm{CH}_{4}\right)$ from perialpine and alpine hydropower reservoirs. Biogeosci Discuss 5:3699-3738

Eller G, Kanel LK, Krüger M (2005) Cooccurrence of aerobic and anaerobic methane oxidation in the water column of lake Plusssee. Appl Environ Microbiol 71:8925-8928

Ettwig KF, Shima S, van de Pas-Schoonen KT, Kahnt J, Medema MH, op den Camp HJM et al (2008) Denitrifying bacteria anaerobically oxidize methane in the absence of Archaea. Environ Microbiol 10:3164-3173

Fenchel T, Blackburn TH (1979) Bacteria and mineral cycling. Academic Press, London

Hinrichs K-U, Boetius A (2002) The anaerobic oxidation of methane: new insights in microbial ecology and biogeochemistry. In: Wefer G, Billett D, Hebbeln D, Jørgensen B, Schlüter M, Van Weering $\mathrm{T}$ (eds) Ocean margin systems. Springer, Berlin, pp 457-477

Hinrichs K-U, Hayes JM, Sylva SP, Brewert PG, DeLong EF (1999) Methane-consuming archaebacteria in marine sediments. Nature 398:802-805

IPCC (2001) Climate change 2001: The Scientific Basis. Contribution of Working Group I to the third assessment report of the intergovernmental panel on climate change. In: Houghton JT, Ding Y, Griggs DJ, Noguer M, van der Linden PJ, Dai X, Maskell K, Johnson CA (eds) Cambridge University Press, Cambridge, $881 \mathrm{pp}$

Iversen N, Oremland RS, Klug MJ (1987) Big Soda Lake (Nevada).3. Pelagic methanogenesis and anaerobic methane oxidation. Limnol Oceanogr 32:804-814

Jørgensen BB (1982) Mineralization of organic matter in the sea bed; the role of sulphate reduction. Nature 296:643-645

Kemp P, Lee S, LaRoche J (1993) Estimating the growth rate of slowly growing marine bacteria from RNA content. J Appl Environ Microbiol 5:2594-2601

Kennett JP, Cannariato KG, Hendy IL, Behl RJ (2000) Carbon isotopic evidence for methane hydrate instability during quaternary interstadials. Science 288:128-133

Kohler H-P, Åhring B, Albella C, Ingvorsen K, Kewelsh H, Laczkó E et al (1984) Bacteriological studies on the sulfur cycle in the anaerobic part of the hypolimnion and in the surface sediments of Rotsee in Switzerland. FEMS Microbiol Lett 21:279-286

Liss PS, Merlivat L (1986) Air-sea gas exchange rates: introduction and synthesis. In: Buat-Menard PE (ed) The role of air-sea exchange in geochemical cycling. Reidel, Dordrecht

Liss PS, Slater PG (1974) Flux of gases across air-sea interface. Nature 247:181-184

Lucas FS, Hollibaugh JT (2001) Response of sediment bacterial assemblages to selenate and acetate amendments. Environ Sci Technol 35:528-534

Lucas FS, Moureau B, Jourdie V, Heeb P (2005) Brood size modification affects plumage bacterial assemblages of European starlings. Mol Ecol 14:639-646

Murase J, Sakai Y, Kametani A, Sugimoto A (2005) Dynamics of methane in mesotrophic Lake Biwa, Japan. Ecol Res 20:377-385

Muyzer G, Dewaal EC, Uitterlinden AG (1993) Profiling of complex microbial-populations by denaturing gradient gel-electrophoresis 
analysis of polymerase chain reaction-amplified genes-coding for 16S ribosomal-RNA. Appl Environ Microbiol 59:695-700

Nauhaus K, Boetius A, Kruger M, Widdel F (2002) In vitro demonstration of anaerobic oxidation of methane coupled to sulphate reduction in sediment from a marine gas hydrate area. Environ Microbiol 4:296-305

Orphan VJ, House CH, Hinrichs KU, McDeegan KD, Delong EF (2002) Multiple archaeal groups mediate methane oxidation in anoxic cold seep sediments. Proc Natl Acad Sci USA 99:76637668

Pancost RD, Damste JSS, de Lint S, van der Maarel M, Gottschal JC (2000) Biomarker evidence for widespread anaerobic methane oxidation in Mediterranean sediments by a consortium of methanogenic archaea and bacteria. Appl Environ Microbiol 66:1126-1132

Panganiban AT, Patt T, Hart W, Hanson RS (1979) Oxidation of methane in the absence of oxygen in lake water samples. Appl Environ Microbiol 37:303-309

Pernthaler A, Preston CM, Pernthaler J, DeLong EF, Amann R (2002) Comparison of fluorescently labeled oligonucleotide and polynucleotide probes for the detection of pelagic marine bacteria and archaea. Appl Environ Microbiol 68:661-667

Raghoebarsing AA, Pol A, van de Pas-Schoonen KT, Smolders AJP, Ettwig KF, Rijpstra WIC et al (2006) A microbial consortium couples anaerobic methane oxidation to denitrification. Nature 440:918-921

Rahalkar M, Deutzmann J, Schink B, Bussmann I (2009) Abundance and activity of methanotrophic bacteria in littoral and profundal sediments of Lake Constance (Germany). Appl Environ Microbiol 75:119-126

Rasband WS (1997-2005) ImageJ, US National Institutes of Health, Bethesda, Maryland, USA. http://rsb.info.nih.gov/ij/

Rasmussen RA, Khalil MAK (1984) Atmospheric methane in the recent and ancient atmospheres: concentrations, trends, and interhemispheric gradient. J Geophys Res 89:1599-1605

Reeburgh WS, Ward BB, Whalen SC, Sandbeck KA, Kilpatrick KA, Kerkhof LJ (1991) Black Sea methane geochemistry. Deep Sea Res 38(Suppl 2):1189-1210

Rudd JWM, Hamilton RD (1975) Factors controlling rates of methane oxidation and distribution of methane oxidizers in a small stratified lake. Arch Hydrobiol 75:522-538
Saarnio S, Winiwarter W, Leitão J (2009) Methane release from wetlands and watercourses in Europe. Atmos Environ 43:14211429

Schmid M, Halbwachs M, Wehrli B, Wuest A (2005) Weak mixing in Lake Kivu: new insights indicate increasing risk of uncontrolled gas eruption. Geochem Geophys Geosyst 6:1-11

Schoell M (1988) Multiple origins of methane in the earth. Chem Geol 71:1-10

Schubert CJ, Coolen M, Neretin L, Schippers A, Abbas B, DurischKaiser E, Wehrli B, Hopmans E, Sinninghe Damsté J, Wakeham S, Kuypers MMM (2006) Anaerobic and aerobic methanotrophs in the Black Sea water column. Environ Microbiol 8(10):18441856

St. Louis VL, Kelly CA, Duchemin E, Rudd JWM, Rosenberg DM (2000) Reservoir surfaces as sources of greenhouse gases to the atmosphere: a global estimate. Bioscience 50:766-775

Stevens CM, Wahlen M (2000) The isotopic composition of atmospheric methane and its sources. In: Khalil MAK (ed) Atmospheric methane. Springer, Berlin, pp 25-41

Sundh I, Bastviken D, Tranvik LJ (2005) Abundance, activity and community structure of pelagic methane-oxidizing bacteria in temperate lakes. Appl Environ Microbiol 71:6746-6752

Ward BB, Kilpatrick KA, Novelli PC, Scranton MI (1987) Methane oxidation and methane fluxes in the ocean surface layer and deep anoxic waters. Nature 327:226-229

Wetzel RG (1983) Limnology, 2nd edn. W. B. Saunders Co., Philadelphia, PA

Wuebbles DJ, Hayhoe K (2002) Atmospheric methane and global change. Earth Sci Rev 57:177-210

Zehnder AJB, Brock TD (1979) Methane formation and methane oxidation by methanogenic bacteria. J Bacteriol 137:420-432

Zehnder AJB, Brock TD (1980) Anaerobic methane oxidationoccurrence and ecology. Appl Environ Microbiol 39:194-204

Zepp Falz K, Holliger C, Grosskopf R, Liesack W, Nozhevnikova AN, Müller B, Wehrli B, Hahn D (1999) Vertical distribution of methanogens in the anoxic sediment of Rotsee (Switzerland). Appl Environ Microbiol 65(6):2402-2408 